\title{
COVID-19 pandemic, healthcare providers' contamination and death: an international view
}

\author{
Hossein Hassanian-Moghaddam ${ }^{1,2^{*}}$ (D), Nasim Zamani ${ }^{1,2}$ and Ali-Asghar Kolahi ${ }^{1}$
}

\section{Dear Editor,}

There is a growing number of healthcare providers (HCPs) who have died as a result of the COVID-19 pandemic. In the past, the 2003 outbreak of severe acute respiratory syndrome (SARS) transmitted the virus to HCPs, who accounted for a fifth of all infected cases globally. Risk factors included poor institutional infection control measures and poor compliance with the use of personal protection equipment (PPE), among others [1]. Although there are novel guidelines for the prevention, quarantine, epidemiology, and treatment of COVID-19, little is known about its rates of occupational transmission to HCPs. At the time of writing, the total number of coronavirus cases in the world has already surpassed two million [2]. In the absence of official data, our preliminary search of media sources shows that $486 \mathrm{HCPs}$ with an average age (SD) of 59 (14) years have died from COVID-19 ([3], Table 1), equivalent to an estimated death toll of $0.36 \%$ of HCPs relative to all registered COVID-19 deaths in the world. Due to limited data and possible underreporting, the true scale of deaths among HCPs remains unknown.

As depicted in the table, there is a huge gap between the highest reported death toll among HCPs in the Philippines (7.16\%) and the lowest in France (0.11\%). Notably, a death toll below $1 \%$ is only listed for highincome countries. Possible reasons for the variety in mortality rates between countries include the levels of preparedness, COVID-19 testing, and availability of PPE,
Table 1 Data on COVID-19 deaths in most affected countries with more than 10 HCP mortality

\begin{tabular}{lllll}
\hline Country & $\begin{array}{l}\text { Total } \\
\text { mortality }\end{array}$ & $\begin{array}{l}\text { Mortality of } \\
\text { HCP }\end{array}$ & $\begin{array}{l}\text { HCP's death } \\
\text { toll (\%) }\end{array}$ & Date of report \\
\hline Italy & 21,645 & 120 & 0.55 & April 7, 2020* \\
Iran & 4777 & 95 & 1.99 & April 16, 2020 \\
USA & 26,047 & 66 & 0.25 & $\begin{array}{l}\text { April 15, } \\
2020^{* *}\end{array}$ \\
UK & 12,107 & 41 & 0.34 & $\begin{array}{l}\text { April 14, } \\
2020^{\otimes}\end{array}$ \\
Spain & 14,792 & 26 & 0.18 & April 08, 2020 \\
Philippines & 335 & 24 & 7.16 & $\begin{array}{l}\text { April 15, } \\
2020^{* *}\end{array}$ \\
China & 1665 & 22 & 1.32 & $\begin{array}{l}\text { February 15, } \\
2020^{\varnothing}\end{array}$ \\
Indonesia & 459 & 17 & 3.70 & $\begin{array}{l}\text { April 15, } \\
2020^{* *}\end{array}$ \\
Brazil & 1532 & 17 & 1.11 & $\begin{array}{l}\text { April 15, } \\
2020^{* *}\end{array}$ \\
France & 13,197 & 15 & 0.11 & $\begin{array}{l}\text { April 10, } \\
2020^{\oplus}\end{array}$ \\
\hline
\end{tabular}

*https://edition.cnn.com/world/live-news/coronavirus-pandemic-04-07-20/h_ b7583ec9fa05d053f6faca9b164817eb

**https://www.medscape.com/viewarticle/927976\#vp_1

${ }^{\otimes}$ https://www.telegraph.co.uk/news/0/nhs-workers-died-coronavirus-frontlinevictims/

${ }_{\text {https://cadenaser.com/ser/2020/04/08/sociedad/1586325379_363621.html }}$ $\varnothing_{\text {www.businessinsider.com/why-coronavirus-killed-young-chinese-doctors-202 }}$ $0-2$

${ }^{\oplus}$ https://www.20minutes.fr/sante/2758699-20200410-coronavirus-parmivictimes-covid-19-france-professionnels-sante-paient-lourd-tribu

\footnotetext{
* Correspondence: hassanian@sbmu.ac.ir

'Social Determinants of Health Research Center, Shahid Beheshti University of Medical Sciences, Tehran 1546817613, Iran

${ }^{2}$ Department of Clinical Toxicology, Loghman Hakim Hospital, School of

Medicine, Shahid Beheshti University of Medical Sciences, Tehran, Iran
}

(c) The Author(s). 2020 Open Access This article is licensed under a Creative Commons Attribution 4.0 International License, which permits use, sharing, adaptation, distribution and reproduction in any medium or format, as long as you give appropriate credit to the original author(s) and the source, provide a link to the Creative Commons licence, and indicate if changes were made. The images or other third party material in this article are included in the article's Creative Commons licence, unless indicated otherwise in a credit line to the material. If material is not included in the article's Creative Commons licence and your intended use is not permitted by statutory regulation or exceeds the permitted use, you will need to obtain permission directly from the copyright holder. To view a copy of this licence, visit http://creativecommons.org/licenses/by/4.0/ The Creative Commons Public Domain Dedication waiver (http://creativecommons.org/publicdomain/zero/1.0/) applies to the data made available in this article, unless otherwise stated in a credit line to the data. 
as well as different protocols around release from the workplace to be quarantined.

In many countries, confirmation of disease is based on clinical characteristics and CT findings and not on possible exposure and laboratory confirmation. Many COVID-19 carriers therefore remain undetected, while HCPs on the frontlines face a high risk of contracting the disease. This includes HCPs working without sufficient PPE in ordinary departments where they face risk of exposure to unsuspected patients as well as HCPs in departments dedicated to confirmed COVID-19 cases.

The US Centers for Disease Control and Prevention have released useful information on interim infection prevention and control recommendations for COVID-19 patients in healthcare facilities, but implementation may not be feasible in low-resource settings with high patient volumes [4]. Therefore, we must stay ahead of the game in preventing the transmission of COVID-19 to HCPs; otherwise, we will quickly run out of human resources even if we have enough supplies. Let us save our rescuers!

\section{Acknowledgements}

None

\section{Authors' contributions}

$\mathrm{HHM}$ helped in the conception and design of the study. AAK, HHM, and NZ contributed to the data collection. NZ helped in the first draft writing. All authors contributed to the final approval of the version to be submitted. All authors read and approved the final manuscript.

\section{Funding}

None

Availability of data and materials

The data is all presented in the text.

Ethics approval and consent to participate

Not applicable

Consent for publication

Not applicable

\section{Competing interests}

The authors declare that they have no competing interests.

Received: 13 April 2020 Accepted: 30 April 2020

Published online: 08 May 2020

\section{References}

1. Chan-Yeung M. Severe acute respiratory syndrome (SARS) and healthcare workers. Int J Occup Environ Health. 2004;10(4):421-7. https://doi.org/10. 1179/oeh.2004.10.4.421.

2. https://www.worldometers.info/coronavirus/, Accessed 16 Apr 2020.

3. In Memoriam: Healthcare Workers Who Have Died of COVID-19. Available through: https://www.medscape.com/viewarticle/927976\#vp_1. Accessed 16 Apr 2020.

4. https://www.cdc.gov/coronavirus/2019-ncov/infection-control/controlrecommendations.html.

\section{Publisher's Note}

Springer Nature remains neutral with regard to jurisdictional claims in published maps and institutional affiliations. 